\title{
PENINGKATAN HASIL BELAJAR PESERTA DIDIK MELALUI PENERAPAN MODEL PEMBELAJARAN DISCOVERY LEARNING
}

\author{
Okta Wulandari ${ }^{{ }^{*}}$ Yennita $^{1}$ dan Irdam Idrus ${ }^{1}$ \\ ${ }^{1}$ Program Studi Pendidikan Biologi, Fakultas Keguruan dan Ilmu Pendidikan, Universitas Bengkulu \\ Email : okthawulandari@yahoo.com
}

\begin{abstract}
Abstrak
Penelitian ini bertujuan untuk mendeskripsikan hasil belajar dengan menerapkan model pembelajaran discovery learning di kelas $\mathrm{VII}_{\mathrm{A}}$ SMPN 3 Pasemah Air Keruh Kabupaten Empat Lawang. Jenis penelitian ini adalah penelitian tindakan kelas dengan metode deskriptif. Penelitian ini terdiri dua siklus, masingmasing siklus terdiri dari 4 tahap yaitu perencanaan, pelaksanaan, pengamatan dan refleksi. Subjek penelitian ini adalah guru dan peserta didik kelas $\mathrm{VII}_{\mathrm{A}}$ SMPN 3 Pasemah Air Keruh Kabupaten Empat Lawang. Instrumen penelitian yang digunakan lembar tes dan lembar observasi. Hasil analisis persentase ketuntasan belajar peserta didik ranah kognitif pada siklus I yaitu 64,28 \% (tidak tuntas) dan pada siklus II meningkat 82,14 \% (tuntas). Sedangkan hasil belajar psikomotor pada siklus I rata-rata skor 13,82 (Cukup) dan hasil siklus II mengalami peningkatan menjadi 14,82 (Baik). Dari hasil penelitian dapat disimpulkan bahwa penerapan discovery learning dapat meningkatkan hasil belajar peserta didik dikelas $\mathrm{VII}_{\mathrm{A}}$ SMPN 3 Pasemah Air Keruh Kabupaten Empat Lawang.

Kata kunci : Discovery Learning, Hasil Belajar
\end{abstract}

\begin{abstract}
This study aims to describe improve learning results by applying discovery learning model in $\mathrm{VII}_{\mathrm{A}}$ grade of SMPN 3 Pasemah Air Keruh of Empat Lawang Regency. Kind of research is classroom action research with descriptive method. This study consists of two cycles, each cyle consisting of four stages, there was :planning, implantation, observation and reflection. The subject of study was teacher and student as participant in $\mathrm{VII}_{\mathrm{A}}$ grade of SMPN 3 Pasemah Air Keruh of Empat Lawang Regency. Instrument was used paper test and observation sheet psychomotor learning asessement result. The results of the analysis of the percentage of learning completeness of cognitive students in the first cycle were 64,28\% (incomplete) and in the second cycle increased $82,14 \%$ (complete). While the psychomotor learning results in the first cycle averaged 13,82 \% (enough) and results of the second cycle experienced a significant increase of 14,82 (good). From the result of the study it could be concluded that the discovery learning model could improve learning and students in $\mathrm{VII}_{\mathrm{A}}$ grade of SMPN 3 Pasemah Air Keruh of Empat Lawang Regency.

Key words : Discovery Learning, Studied Results
\end{abstract}




\section{PENDAHULUAN}

Pendidikan adalah karya bersama yang berlangsung dalam suatu pola kehidupan insani tertentu dan suatu sistem yang dikelompokkan menjadi dua sistem, yaitu yang pertama sistem mekanik dan yang kedua sistem organik. Sistem mekanik adalah melihat pendidikan sebagai suatu proses yang melibatkan input-proses-output yang terdapat hubungan kausal bersifat langsung dan linear. Menurut Sagala (2009), Undang-Undang Republik Indonesia No 20 Tahun 2003 tentang Sistem Pendidikan Nasional Bab 1 Pasal 1 menyatakan bahwa pendidikan adalah usaha sadar dan terencana untuk mewujudkan suasana belajar dan proses pembelajaran agar peserta didik secara aktif mengembangkan potensi dirinya untuk memiliki kekuatan spiritual, keagamaan, pengendalian diri, kepribadian, kecerdasan, akhlak mulia, serta keterampilan yang diperlukan dirinya, masyarakat, bangsa, dan negara.

Berdasarkan hasil observasi dan wawancara dengan guru Biologi dikelas $\mathrm{VII}_{\mathrm{A}}$ SMPN 3 Pasemah Air Keruh Kabupaten Empat Lawang terhadap pembelajaran IPA Biologi disekolah tersebut, diperoleh informasi sebagai berikut: 1) pembelajaran yang berpusat pada guru; 2) peserta didik belum berperan aktif dan mandiri untuk mengembangkan pengetahuan mereka dan mencari bahan-bahan pendukung pembelajaran mereka sendiri, karena setiap pembelajaran masih mengadalkan guru; 3) pada setiap materi ajar yang diberikan pada peserta didik, guru lebih sering menggunakan metode ceramah dan diskusi dan mata pelajaran IPA Biologi jarang sekali melakukan praktikum; 4) dalam proses belajar dan mengajar, guru belum menggunakan LKPD dalam membantu proses pembelajaran dan pemahaman materi dikelas; 5) hasil belajar peserta didik masih rendah. Adapun KKM yang ditetapkan SMP Negeri 3 Pasemah Air Keruh Kabupaten Empat Lawang adalah 75.

Pembelajaran discovery learning merupakan proses pembelajaran yang dilakukan tanpa penyajian pelajaran dan hasil akhirnya. Discovery learning ialah penemuan konsep dengan serangkaian data/informasinya yang didapatkan lewat pengamatan maupun percobaan (Hurniasih, 2014). Menurut Hosnan (2014), pengertian discovery learning ialah model pengembangan cara belajar aktif dengan mendapatkan berpikir dan mengkaji sendiri, maka hasil yang didapatkan bisa terus diingat. Dengan menggunakan metode belajar ini, peserta didik dapat belajar berpikir menganalisa dan memecahakan masalahnya.

Dalam pembelajaran discovery learning (penemuan) yang kegiatan atau pembelajaran yang dirancang sedemikian rupa sehingga peserta didik dapat menemukan konsep-konsep dan prinsipprinsip melalui proses mentalnya sendiri, diantaranya : 1) terlibat secara aktif dan bepartisipasi, 2) belajar menemukan pola dalam situasi kongkret maupun abstrak, 3) merumuskan masalah, 4) bekerja sama, saling membagi informasi serta menggunakan ide-ide, 5) keterampilan dan menemukan konsep yang dipelajari, 6) keterampilan mengaplikasikan situasi belajar yang baru (Gumalisa, 2015). 
Penelitian relevan yang menggunakan model discovery learning yaitu penelitian yang dilakukan Mulyanti (2015) menunjukkan bahwa hasil penelitian dengan menggunakan model discovery learning dapat meningkatan aktivitas guru dan aktivitas peserta didik dan hasil belajar.

\section{METODE}

Jenis penelitian yang dilakukan adalah Peneltian Tindakan Kelas (PTK). Kunandar (2011), berdasarkan model Kemmis dan Mc Taggart penelitian tindakan kelas memiliki empat tahapan yaitu perencanaan, pelaksanaan, observasi, dan refleksi. Penelitian tindakan kelas dilaksanakan sesuai dengan tujuan peneliti yaitu untuk meningkatkan hasil belajar peserta didik kelas $\mathrm{VII}_{\mathrm{A}}$ SMPN 3 Pasemah Air Keruh kabupaten Empat Lawang dengan menerapkan model model pembelajaran discovery learning pada materi fotosintesis. Menurut Kunandar (2011) discovery learning adalah metode pembelajaran yang memiliki sintak sebagai berikut: 1) pemberian rangsangan (stimulation); 2) identifikasi masalah (problem statement); 3) pengumpulan data (data collection); 4) pengolahan data (data processing); 5) pembuktian (verification); 6) menarik kesimpulan (generalation). Subyek penelitian ini adalah guru dan seluruh peserta didik kelas $\mathrm{VII}_{\mathrm{A}}$ SMPN 3 Pasemah Air Keruh Kabupaten Empat Lawang yang berjumlah 28 orang peserta didik terdiri 14 laki-laki dan 14 perempuan.

Teknik pengumpulan data dalam penelitian ini yaitu observasi dan tes. Sedangkan instrumen penelitian yang digunakan adalah lembar observasi dan lembar tes, dalam penelitian ini yang mengembangkan instrumen saya sebagai guru dan lembar validitasnya guru IPA SMPN 3 pasemah Air Keruh, Lembar observasi digunakan untuk menilai hasil belajar ranah psikomotor peserta didik selama proses praktikum dalam pembelajaran dengan model pembelajaran discovery learning. Lembar tes digunakan untuk menilai hasil belajar ranah kognitif dengan bentuk soal pilihan ganda. Teknik analisis data hasil belajar peserta didik ranah kognitif dianalisis dengan menghitung nilai rata-rata serta menentukan persentase hasil belajar secara klasikal. Data rata-rata observasi hasil belajar peserta didik ranah psikomotor dapat dihitung menggunakan rumus :

Rata-rata skor $=\frac{\text { jumlah } \text { skor }}{\text { jumlah pengamat }}$

(Arikunto, 2012).

Kategori data observasi hasil belajar ranah psikomotor peserta didik dapat dilihat pada Tabel 1.

Tabel 1. Kategori Penilaian Psikomotor Peserta Didik Siklus I

\begin{tabular}{cl}
\hline Rentang skor & Kategori Penelitian \\
\hline $6-9$ & Kurang \\
$10-13$ & Cukup \\
$14-18$ & Baik \\
\hline
\end{tabular}

Sedangkan untuk menghitung ratarata hasil belajar peserta didik ranah kognitif menggunakan rumus Trianto (2010)

a) Rerata dihitung dengan menggunakan rumus:

Keterangan:

$$
\mathrm{X}=\frac{\sum \mathrm{X}}{\sum N}
$$

$\mathrm{X}=$ Nilai rata-rata peserta didik 
$\sum \mathrm{x} \quad=$ Jumlah nilai peserta didik

$\Sigma N \quad=$ Jumlah peserta didik

b) Ketuntasan belajar klasikal dihitung menggunakan rumus sebagai berikut:

$\mathrm{q}=\frac{\text { peserta didik yang tuntas belajar }}{\sum \text { siswa }} \times 100 \%$

Keterangan:

$\mathrm{q}=$ ketuntasan belajar klasikal

$\Sigma=$ peserta didik yang tuntas belajar (jumlah peserta didik yang memperoleh nilai $\geq 75$ )

$\Sigma$ peserta didik= jumlah seluruh peserta didik

\section{HASIL DAN PEMBAHASAN}

Berdasarkan penelitian yang telah dilakukan data observasi hasil belajar ranah psikomotor peserta didik dalam kegiatan pembelajaran dengan menggunakan model pembelajaran discovery learning pada siklus I dan siklus II dapat dilihat pada Tabel 2.

Tabel 2. Hasil Belajar Peserta Didik Ranah Psikomotor pada Siklus I dan Siklus II

\begin{tabular}{lcc} 
& \multicolumn{3}{c}{ Siklus } \\
& $\mathrm{I}$ & II \\
\hline Rata-rata & 13,82 & 14,82 \\
\hline Kriteria & Cukup & Baik \\
\hline
\end{tabular}

Berdasarkan Tabel 2 dapat diketahui bahwa hasil belajar ranah psikomotor siklus I diperoleh rata-rata 13,82 dengan kriteria cukup, sedangkan pada siklus II diperoleh 14,82 dengan kriteria baik. Hal ini berarti terjadi peningkatan hasil belajar ranah psikomotor dari siklus I ke siklus II.

Hasil belajar peserta didik siklus I dan siklus II ranah kognitif diperoleh data berdasarkan hasil tes dapat dilihat pada Tabel 3.
Tabel 3. Hasil Belajar Peserta Didik Ranah Kognitif pada Siklus I dan Siklus II

\begin{tabular}{lcc}
\hline & \multicolumn{2}{c}{ Siklus } \\
& I & II \\
\hline Rata-rata & 78,57 & 90 \\
Persentase & & \\
Ketuntasan & $71,42 \%$ & $85,71 \%$ \\
Hasil Belajar & & \\
\hline Kriteria & Tidak Tuntas & Tuntas \\
\hline
\end{tabular}

Dari Tabel 3 diatas dapat dilihat bahwa persentase ketuntasan klasikal peserta didik siklus I 71,42 \% meningkat menjadi 85,71 \% pada siklus II. Peningkatan hasil belajar ranah psikomotor dan ranah kognitif dari siklus I ke sikus II disebabkan karena meningkatnya aktivitas peserta didik selama proses pembelajaran. Model pembelajaran discovery learning yang terdiri dari 6 sintak pembelajaran yaitu sebagai berikut :

a) Stimulation/ Pemberian Rasangan

Pada sintak pemberian rasangan yaitu untuk menyediakan kondisi interaksi belajar, guru menuliskan dan menyampaikan tujuan pembelajaran. Disampaikan dalam proses pembelajaran berlangsung peserta didik dapat mengembangkan kemampuan berpikir kreatif dalam mengorganisasikan proses pembelajaran yang disajikan oleh guru, hal ini sesuai dengan Rusman (2014), bahwa tujuan pembelajaran mengambarkan proses dan hasil belajar yang diharapkan dicapai oleh peserta didik.

Pada tahap guru menyajikan fenomena tentang bagaimana proses fotosintesis dalam kehidupan sehari-hari dan guru mengajukan pertanyaan yang berkaitan dengan fotosintesis. Tahap ini dilakukan agar peserta didik termotivasi 
untuk belajar, aktif dalam proses pembelajaran dan dapat menggali kemampuan awal peserta didik. Hal tersebut selaras dengan pendapat Wijaya (2015), bahwa selama proses belajar peserta didik dituntut aktif untuk mendengarkan, memperhatikan dan mencerna pelajaran yang diberikan guru, disamping itu sangat dimungkinkan peserta didik memberikan umpan balik pertanyaan, gagasan, pikiran, perasaan, dan keinginannya. Sukardi (2013) juga menyatakan bahwa proses pembelajaran yang berkesan akan membangkitkan minat serta motivasi peserta didik yang akan melahirkan suatu aktivitas belajar dan berakhir pada prestasi belajar yang baik.

\section{b) Problem statement (Pernyataan/ Identifikasi Masalah)}

Setelah dilakukan stimulation guru memberikan kesempatan kepada peserta didik untuk mengidentifikasi sebanyak mungkin masalah yang relevan dengan bahan pelajaran, kemudian salah satunya dirumuskan dalam bentuk hipotesis (jawaban sementara atas pertanyaan masalah) yang diberikan guru. Hal ini selaras dengan peranan guru menurut Rusman (2014), bahwa salah-satu peran guru dalam proses pembelajaran yaitu sebagai fasilitator, dimana guru membimbing peserta didik selama kegiatan pembelajaran berlangsung.

Pada tahap selanjutnya guru membagikan lembar kerja peserta didik dan menjelaskan langkah kerja. Hal ini bertujuan agar peserta didik dapat dengan mudah memahami langkah-langkah pengamatan yang akan dilakukan pengamatan dapat dilakukan sehingga pengamatan dapat terlaksana dengan baik. Hal ini selaras dengan pendapat Sukardi (2013) yang menyatakan aktivitas belajar peserta didik menyangkut bagaimana usaha peserta didik untuk mengorganisasikan dalam pembelajaran yang disampaikan pendidik. c) Data Collection (Pengumpulan Data) Pada saat peserta didik melakukan eksprimen atau eksplorasi, guru memberikan kesempatan kepada peserta didik untuk mengumpulkan informasi sebanyak-banyaknya yang relevan untuk membuktikan benar atau tidaknya hipotesis, data dapat diperoleh melalui membaca literature, mengamati objek, dan melakukan uji coba sendiri dan sebagainya. Pada tahap sesuai dengan pendapat Sani (2013) yang menyatakan bahwa pembelajaran discovery learning memungkinkan peserta didik untuk terlibat sendiri dalam belajar mengali informasi, bekerja sama dan belajar keterampilan komunikasi.

d) Data Processing (Pengolahan Data)

Pada tahap pengolahan data guru membimbing peserta didik mengolah data dan informasi yang telah diperoleh peserta didik melalui observasi, dan sebagainya, lalu ditafsirkan. Dalam tahap ini peserta didik mencatat hasil yang didapat agar mempermudah peserta didik dalam mengingat dan memahami materi yang telah diberikan guru. Hal tersebut selaras pendapat Sudjana (2008), bahwa salah satu aktivitas peserta didik dalam proses pembelajaran yaitu dalam mengorganisasikan, mencatat dan menafsirkan data yang diperoleh yang dianggap penting menyangkut materi yang sedang dipelajari. 
e) Verification (Pembuktian)

Pada tahap ini peserta didik melakukan pemeriksaan secara cermat untuk membuktikan benar atau tidaknya hipotesis yang telah ditetapkan, dihubungkan dengan hasil data processing. Berdasarkan hasil pengolahan data tafsiran, atau informasi yang ada, pernyataan atau hipotesis yang telah dirumuskan terdahulu itu kemudian peserta didik dibuktikan sendiri, apakah terjawab atau tidak, apakah terbukti atau tidak.

f) Generalization (Menarik Kesimpulan)

Pada tahap generalisasi/menarik kesimpulan, guru memberikan kesempatan dimana peserta didik menarik kesimpulan yang dapat dijadikan prinsip umum dan berlaku untuk menyelesaikan masalah yang diberikan guru sesuai dengan materi pembelajaran yang disampaikan kemudian peserta didik memperhatikan hasil verifikasi. Berdasarkan hasil verifikasi maka dirumuskan prinsip-prinsip yang mendasari generalisasi.

Tujuan guru memberikan refleksi yaitu memperbaiki hasil diskusi yang telah disampaikan oleh peserta didik dan mengaitkan dengan teori terkait materi yang diajarkan. Hal ini didukung oleh pendapat Nur dan Ismail (2002) dalam Rusman (2014) bahwa aktivitas guru pada sintaks pembelajaran discovery learning bahwa proses identifikasi masalah dan pengumpulan data guru hanya membimbing peserta didik dalam mengorganisasikan untuk mencari tau dan menemukan sendiri data yang akan diperoleh.

Tahap kedua guru membimbing kelompok peserta didik mengumpulkan data/informasi yang sesuai dengan hasil pengamatan. Pada kegiatan ini dilakukan diskusi dengan bekerja sama dengan kelompok untuk menemukan sendiri atau mencari tau data-data yang akan dipelajari, sehingga pada tahap ini peserta didik dalam mencari data atau informasi bersama dengan anggota kelompoknya dalam proses pengumpulan data yang baik dari hasil pada aspek ini yang dilakukan peserta didik pada aspek ini yaitu menjawab pertanyaan pada lembar kerja sesuai dengan hasil diskusi yang dilakukan untuk memecahkan masalah dari hasil pengamatan yang telah dilakukan. Hal ini selaras dengan pendapat Sani (2014), yang menyatakan bahwa model pembelajaran discovery learning menuntut peserta didik untuk mampu aktif, kreatif, inovatif dalam memecahkan masalah yaitu dengan menemukan sendiri konsepnya dan guru berperan sebagai pembimbing dalam memecahkan masalah.

Tahap ketiga yaitu guru meminta peserta didik untuk mengumpulkan lembar kerja peserta didik. Pada tahap ini kegiatan guru dan peserta didik terlaksana dengan baik. Pada tahap ini semua kelompok yang mengumpulkan lembar kerja peserta didik yang sudah dikerjakan untuk dinilai oleh guru. Tahap ini bertujuan agar guru dapat mengetahui kemampuan peserta didik dalam menemukan konsep sendiri. Hal ini selaras dengan pendapat Ibrahim (2017) yang menyatakan bahwa konsep menemukan sendiri dan mampu mengorganisasikan dapat meningkatkan aktivitas belajar peserta didik, membantu peserta didik mengembangkan pengetahuan serta mudah mengingat pembelajaran yang mereka temukan sendiri dan sebagai bekal dalam proses belajar 
dapat digunakan sebagai meningkatkan minat belajar peserta didik.

Tahap keempat yaitu guru memberikan evaluasi berupa post test. Evaluasi yang diberikan yaitu tes tertulis berupa soal objektif dalam bentuk pilihan ganda yang dibuat sesuai indikator berjumlah 10 buttir soal. Evaluasi yang diberikan bertujuan untuk melihat kemampuan peserta didik dalam mencapai berbagai tujuan pembelajaran dijelaskan. $\mathrm{Hal}$ ini sesuai dengan pendapat Nafiah dan Suyanto (2014), berhasil atau tidaknya suatu pembelajaran discovery learning pada peserta didik dianalisis dengan melihat hasil tes yang telah diberikan melalui post test.

Berdasarkan dengan uraian dengan tahapan model pembelajaran discovery learning diatas, maka dapat disimpulkan bahwa aktivitas guru sangat menentukan aktivitas peserta didik. Jika aktivitas guru dalam melakukan pembelajaran dikelas baik, sehingga aktivitas peserta didik dan hasil belajar peserta didik juga akan baik begitupun sebaliknya. Hal ini selaras dengan pendapat Wulandari dan Surjono (2013) menyatakan bahwa guru merupakan faktor yang paling dominan yang menentukan kualitas pembelajaran. Kualitas pembelajaran yang baik, tentu akan menghasilkan hasil belajar yang baik pula.

Berdasarkan analisis data terjadi peningkatan pada ranah kognitif dari siklus I dan siklus II dengan ketuntasan 75\%. Pada siklus I jumlah persentase ketuntasan belajar peserta didik secara klasikal yaitu $71,42 \%$. Sedangkan pada siklus II jumlah persentase ketuntasan belajar klasikal peserta didik meningkat menjadi $85,71 \%$. Peningkatan jumlah persentase hasil belajar klasikal ranah kognitif dari siklus I ke siklus II menunjukkan bahwa model pembelajaran dicovery learning dapat meningkatkan hasil belajar peserta didik, hal ini didukung oleh penelitian yang dilakukan Mulyanti (2015) yang menyatakan bahwa penerapan pendekatan saintifik dengan model discovery learning pada pembelajaran IPA Biologi dengan materi transportasi pada manusia dapat meningkatkan hasil belajar peserta didik siklus I 63,33\% di siklus II meningkat menjadi $86,66 \%$. Selanjutnya penelitian Novita (2018) menyimpulkan bahwa model pembelajaran discovery learning dapat meningkatkan hasil belajar peserta didik.

Hasil belajar peserta didik ranah psikomotor dalam proses pembelajaran dilakukan dalam 2 siklus menggunakan LKPD. Penilaian hasil belajar ranah psikomotor dilakukan saat peserta didik melakukan praktikum. Proses pembelajaran discovery learning konsepnya menemukan sendiri dan mencari informasi dari berbagai literatur lalu melakukan penyelidikan pengamatan untuk menemukan data yang akurat. Hal tersebut selaras dengan pendapat Abdurrozak dkk (2016) yang menyatakan pembelajaran discovery learning yaitu belajar menemukan untuk menciptakan, menggabungkan, dan menggeneralisasi pengetahuan, berpusat pada peserta didik, kegiatan untuk menggabungkan pengetahuan baru dan pengetahuan yang sudah ada selain hal tersebut peserta didik juga dapat mengingat konsep yang baru dipelajari dalam waktu yang lebih lama karena peserta didik menemukan sendiri konsep yang ada.

Hasil belajar peserta didik pada siklus I ranah psikomotor diperoleh hasil 
13,82 dengan kategori cukup dan meningkat di siklus II dengan perolehan rata-rata 14,82 dengan kategori baik. Berdasarkan hasil observasi dapat dikatakan bahwa peserta didik aktif selama proses pembelajaran berlangsung. Hal ini selaras dengan pendapat Rusman (2014) menyatakan bahwa pembelajaran discovery learning pembelajaran discovery learning yaitu belajar menemukan untuk menciptakan, menggabungkan, dan menggeneralisasi pengetahuan, berpusat pada peserta didik, kegiatan untuk menggabungkan pengetahuan baru dan pengetahuan yang sudah ada, selain hal tersebut peserta didik juga dapat mengingat konsep yang baru dipelajari dalam waktu yang lebih lama karena peserta didik menemukan sendiri konsep sendiri dengan model discovery learning.

\section{PENUTUP}

\section{Simpulan}

Perbaikan pembelajaran dengan menerapkan model pembelajaran discovery learning pada materi fotosintesis dapat meningkatkan hasil belajar peserta didik di kelas $\mathrm{VII}_{\mathrm{A}}$ SMPN 3 Pasemah Air Keruh Kabupaten Empat Lawang pada ranah kognitif dengan ketuntasan belajar klasikal dari $71,42 \%$ menjadi $85,71 \%$ dan dalam ranah psikomotor pada siklus I dengan ratarata skor psikomotor peserta didik dari 13,82 mengalami peningkatan di siklus II menjadi 14,82 dengan kriteria baik.

\section{Saran}

Diharapkan untuk peneliti selajutnya, agar melakukan penelitian lebih lanjut mengenai model pembelajaran discovery learning pada materi pembelajaran yang lain, sehingga diperoleh hasil yang lebih maksimal.

\section{DAFTAR PUSTAKA}

Abdurrozak,R., Jayadinata. K. A., dan Atun. T 2016. Pengaruh Model Discovery Learning Terhadap kemampuan Berpikir kreatif Siswa. Jurnal Pena IImiah, 1 (1):873-874.

Arikunto, S. 2012. Prosedur Penelitian Suatu Pendekatan Praktik. Jakarta : Rineka Cipta.

Novitha Fidya, 2018. Peningkatan Aktivitas Dan Hasil Belajar Melalui Model Discovery Learning Dengan Pendekatan Saintifik. Jurnal Diklabio, $2(2):$ 1-8.

Gumalisa, 2015. Dasar-Dasar Evaluasi Pendidikan. Jakarta : Bumi Akasara.

Hosnan, M. 2014. Pendekatan Saintifik dan Kontekstual dalam Pembelajaran Abad 21. Jakarta : Ghalia Indonesia

Ibrahim. 2017. Perpaduan Model Pembelajaran Aktif Konvensional (Ceramah) Dengan Cooperatif (Make - A Match) Untuk Meningkatkan Hasil Belajar Pendidikan Kewarnegaraan. Jurnal IImu Pendidikan Sosial, Sains, Dan Humaniora, 3 (2) : 201-210.

Kunandar. 2011. Langkah Mudah Penelitian Tindakan Kelas Sebagai Pengembangan Profesi Guru. Jakarta: Rajawali Pers.

Kurniasih, 2014. IPA Terpadu Jilid 1 Kelas VII $S M P$. Jakarta: Erlangga 
Mulyanti. 2015. Belajar Dan Pembelajaran. Bandung: PT Remaja Rosdakarya.

Nafiah, N. Y. Dan Suyanto, W. 2014. Penerapan Model Discovery Learning Untuk Meningkatakan Keterampilan Berfikir Kritis dan Hasil Belajar Siswa. Jurnal Pendidikan Vokasi, 4 (1): 140.

Rusman. 2014. Model-model Pembelajaran Mengembangkan Profesionalme Guru. Jakarta: Rajawali Pers

Sani, A. R. 2013. Pembelajaran Saintifik Untuk Implementasi Kurikulum. Jakarta: Bumi Aksara.

Sani, A. R. 2014. Strategi Belajar Mengajar. Jakarta: Bumi Aksara.

Sudjana. 2008. Dasar-dasar Proses Belajar Menagajar. Bandung: Sinarbu

Sukardi, V. H. 2013. Penerapan Model Pembelajaran Discovery Learning Untuk Meningkatkan Hasil Belajar Biologi Peserta didik kelas VIII SMPN 1 Pondok Kelapa. Skripsi UNIB. Tidak Dipublikasi.

Trianto. 2010. Model Pembelajaran Terpadu. Jakarta: Bumi Aksara

Undang-Undang RI Nomor 20 Tahun 2003. Tentang Sistem Pendidikan Nasional. Jakarta : Bidang Dikbud KBRI Tokyo.

Wijaya, S.R.2015. Hubungan Kemandirian Dengan Aktivitas Belajar Siswa. Jurnal Penelitian Tindakan Bimbingan \& Konseling, 1 (3) : 41
Wulandari, B., Surjono.D.H. 2013. Pembelajaran Discovery Learning Terhadap Hasil Belajar Ditinjau dari Motivasi Belajar PLC di SMK. Jurnal Pendidikan Vokasi 3 (2): 179. 